\title{
遗稿から見を木下圭太郎 (上)
}

書物同好会から出した「書誌」といら 雑誌に，「医家文壇将来記」を書いたの が, 大正の震災で何もかも焼けた東大の 図書館に, 鷗外手択の蔵書数万冊が寄贈 され，その整理を初めた大正 14 年ごろ であつた。小酒井不木, 正木不如丘, 木 下圭太郎等が,「脈」「医文学」などで, 盛 几に文名をはせて，行きずまつた当時の 文壇に，異彩ある進路によつて，打開の 感を与えるものだと記したのであつた。 それからすでに 30 年, 木下圭太郎が戦 後間もなく, 食べもの好多の文人らしい 胃癌で, あわただしい世相をよそに逝い てからも，てとしは満 10 年になる。

山形の疎開先きから, 圭太郎先生の図 書稿本の類を持帰つたり，乙れを整理し たりした。その当時のノートが出て来た ので，随想を少しばがかかつまんでみ ようと思らのであるが，詩才は白秋より も豊かであるとか, 多角的な文化人であ つたととは，「食後の唄」に白秋が序を からたり，木下圭太郎詩集などで，広く 世知られているから, 詩人または作家 としての圭太郎は，ことに略すととにす

画人一鷄外, 濑石, 藤村等と, 初め て交つたのは, 上田敏博士の洋行送別会 であつたが，初めて鷗外の宅を訪ねたの は, 明治 41 年 10 月の歌の会で, その 後, 屡々足を運んだらしい。明治 42 年 「昂」3 月号の裹表紙に, 例の鷊外宅の歌 会の図があり，ローマ字で木下圭太郎と これに自署して1枚保存してあるとてろ から見ると, 同年 2 月 6 日の歌の会で, 彼れがスケッチしたものと思われる。乙 れには鷗外, 同令嬢, 左千夫, 寛 (与謝 野), 信綱 (佐々木) の5人を描いて, 各 々との名を入れている。
明治 45 年 1 月のスバルの裏表紙など, その他雑誌の表紙ではザムボアとか，鉄 門にからたり, 昭和 8 年 7 月 9 日の日記 r, 谷崎潤一郎氏 $K$, 青春物語の表紙, 試刷, カット 2 枚郵送すの記事もあり, その他, 新村博士のちぎれ雲の外, 翮外 訳のファストなど数多く装幀したことが 知られる。自著の装幀が多い中に, 厥後 集の表紙絵の図案が 2 種とその版画があ り, その他は枇杷, 白藤, 宝珠など, 装 幀用の図案がある。

枇杷や紫陽花などのような, 植物を好 んで画題につかわれた。時習会の植物採 集で, 箱根, 伊豆半島, 逗子の神武寺な ぞ, 方々に出かけて, 採集されたものを 写生したり, 標本にされたのである。が, 何で夕手当り次第に描いたので, 日記を つけているとてろへ, 蝿とか蛾, 大蝶な ぞが，空辺に飛びこんだといつて，日記 のかたすタに描いたのが屡々見あたる。 スケッチにも随分と出かけたが，旅先き で紙がない時には，ハガキにかいたり， 仙台からでて, 竜名館の座敷をかいたか と思らと, アンコオルのホテルで, 猫や 植木鉢を描らたり，ホテルの空からアン コオル・トムの遠望を画くという風で, 寸睱を惜んでかいた。

昭和 10 年 77 月 14 日午後 4 時 45 分, 西那須野, 5 分間停車」と記して, 駅前の大桐を描いている。その早いとと も, 煙草をの久ながら, 4 枚かいたとか, 小宮豊隆氏らと, 羽黒山で黒川能を見た とをも,獅子面を写真にとるといらので, 写真機を調整して, 乾板を入れたり, シ ヤッタを切る間に，「何らだ，\&5出来て しまらたぜ」と, 写生帳を見せる早さ， しか夕，資料として立派なものだと，一 行が驚いた浪どであつた。大学の研究室 
でも，独特なアクセントのある，糸状菌 の絵を描らたかと思うと, 教授会では, 紙片に 10 数面, いつの間にか, スケッ チされた，人物画が残されている。

「文学の故に, 本業の造詣を疑われ，余 技の故に，小倉にやられ，実は左遷であ る」と, 鷊外伝をからた, 圭太郎教授の 心情はどんなものであつたろらか，本格 的なものも，数多く残されたが，遺稿か らその絵心を久ると，らまずたゆまず， 絵をかくととは，心から好きであり，そ の意欲は画業人もはるかに及ばないもの があつた。

美術鑑賞——絵をからたばかりでない。 明治 41 年 23 歳ごろから, 文展の批評 を時事や読売に，また新芸術の先駆者と して, 二科展を評し, 大正 5 年 9 月南 満の医学堂, 後の満洲医大に赴任したた めか, その後しばらく美術評はたえたが, （追記「六冊の観画備忘録は僕のノート ブックだが，満洲にゆくようになつて， すべての計画は,夢となつた。」といつて いる。）整複の音の感味として「コスモス 会の諸子に与う」とか, 浜田葆光, 南, 有馬, 栗原忠二の各作品展, 黒田清輝の 遺作展，光風会，フェウザン会の岸田劉 生を評するとか, 口ダンの彫刻を読売に かくとか, 印度小品展を久ては，日本古 仏像を論じ「最近画壇の推移」を新日本 に,「最近の美術界」を太陽に書的たりし た。

満鉄に行つてからでも, 中央美術に南 画を論じ, 洋行先きでは, ケルン市の国 際美術展を評して，海外消息としたりし た。その後，東北美術展の審査員をした り, 東大医学生の踏朱会の会長となつた り, 朝日に院展を評する旁ら, 奉天洋画 会の画展をやつたりしたが，その最活 発にふるまつたのは, 何といつても, 明 治 44 年 6 月, 中央公論飞「画界近事」 をかいたてろから，松本博士著の「現代
の日本画」を評した。大正 4 年どろの少 壮時代であろら。その間, 白馬会や太平 洋画会を評し, 小寺健吉の画展, 中沢, 山本氏の写生画展を評するなど, 自分が 描くことも好きであつたと同時に，意の 和もむくにまかせて，大小ととを選ばず， 無数に画展の批評をしたのである。

読書一一仙台に居られた昭和 8 年 11 月 18 日, 露伴全集の芭蕉七部集抄を, 殆ん どよ久おえた。とれはすでに単行本で， 読んだてとがあるので，短時間で閲する てとができたといつている。それから群 書類従の連歌の部々, 新古今集の春の部 をよんだ。が，午前 2 時頃に，暖炉をた 初めたので，寒くなかつたといつてい る。そしてての頃，色々な歌集をよんだ。 藤原俊成の長秋詠藻をよんで，その甚だ 面白いのを始呚つたといい，山家集 はこれに比べると浅薄だといつている。 また, 鷗外全集, 紅葉集, 监遥集, 思的 出す人々などをよんだが，当世書生気質 など少しもよいとでろがない，紅葉の色 ざんげ，多情多恨もつまらない。かく比 較するとやはり露伴が一番よいといつて 和和 9 年 1 月 20 日ごろ, 「幸田露伴」 を書いた（その 4 月改造社日本文学講座 所収) が，乙の年連句もやつたらしい。 昭和 10 年の正月江, 連歌史を読久初め, 和歌俳諧の歴史を知ろらとしたといつ て, その 4 月に，芭蕉，夢村に関するも のをかいた。

欧蘇手簡を読んで「雨昼夜不止者十余 日，門外水天相接」と的言葉は，少し 誇張したよらだが，大河でもあつたのだ ろらといつたり, 心穏かでなかつたので, 論語を読夕「衣㭪縕袍」の句 (子罕第九) そ至つて，心がはじめて和らかになつた といつている。かように時々㔖飛な本8 よむが，概して，読書してはてれを批評 し，てれらのものを資料としては, 著述 となつた。しかし著述のための読書では 
なく，機会あるごとに調査し，とれに基 らて読書をした。そしててれを批判し， 講演となつたり著述に織りてまれたよう である。

昭和 15 年の夏，即興詩人をよみ； 7 日 夜翮外全集を拾いよ外して，8 日に「鷗 外先生の文章」をかいている。との 21 日 には, 終日アナトオル・フランスの数書 を拾的々，8月 16 日飞，林悟堂の「北 京の白」をよんだり，或は左氏会嘎を精 読しょらと思いたつて，てれを読夕はじ めたが，知らない字は，一々辞書でしら べまた書きぬををしたとい〉，結局読 書はその全生活加ら，きり離せないもの であり，ての文化人の生涯にわたつて， 大きな部分をしめているといえよう。

書評一一読書の傍ら書評も少くない。文 芸春秋に「本の批評」をかき，天草本伊 曽保物語批評を大毎に，また書物展望に 「本・図書館」を，「書物」に，「二十年前 の今日此頃」などを書いた。

朝 9 時から, 夕 6 時まで, 公用につと める身にとつては，夜食を廃せぬ限り， 図書館は利用できないといっながら，東 大図書館で色々な本を覚えたといつてい よらに，後来まで屡々図書館には見え られた。

その他書評として，アガール氏の仏領 印度支那の邦訳評をかき，吉利支丹の稀 覯書について講演したのを, 雑誌にか〉 げたり,浜田青陵の「天正遺欧使節記」評 を朝日K，姉崎正治の「切支丹伝道の興 廃評を東日に, 会津八一氏の渾剤随筆を 評したり，或は吉利支丹関係少くない ととは,広く世に知られたとてろである。 厚生省主催の「小島の春」を久て,「出 来甚だよろし，原作の故なり，配置も佳 なり」などっ，依頼をらけては，小島の 春の感興をかくなど，映画評をである。 尤も早い頃は，劇評もした。新富座の
「椀久」とか「生玉心中」「歓楽の鬼」な ぞを「昂」にかいたり，時事に「エレク トラの実演を虽ふ」をかいたり玄人筋の ものである。

その他徒然一岩波の日本文学に，「森 林太郎」をかいて，豊熟時代の小説，年 夕を打談義のよらだといつたが，その後， また鷗外全集の半ばをよみ, 昭和 17 年 9 月 27 日には, 和談義臭らと思つたが， 単に挑談義や説明䓡ばかりでない，あの 頃の森さんの小説のらちには，朗らかさ の間に，寂しタが感じられる。この寂し みが，殊に今の㒒には，腹の底まで，し みじみと感じられるとい〉，一生休みな き精進で, あれだけの仕事をした鷗外が， レたるとてろに, 寂全の情が感じられる。 てれは余の漸く老々た心に因るであろう かと，歎声をもらした。

研究や仕事をあれ质ど楽しみにした圭 太郎が，一番悲哀を感じたのは, 恐らく 昭和 12 年東北大学加東大に, 皮膚科 三代目の主任教授として，赴任されたて ろであるらしい。

その 8 月 24 日「和机は毎日考えてい る」とか，9月18日「東京にすむとと， すでに 4 カ月に垂んとする」といつたか と思うと，11月 7 日，「今になつて啄木 の歌の気持を味ら泒ど困つた。東京の招 聘に応じたととが，大失敗であつた，い よいよそ扎が明瞭になつた。辞職する訳 にもゆかないとい〉，12月 26 日アナト トオル・フランスの「パリに出て来たべ ルジュレェ君」を読む，それが今の自分 であるといつている。

てのメモを書いてから，木下圭太郎全 集も出たのであるから，次になるべく全 集に出ててなら方で, 旅や食べものにつ いて記してぬよう。

*中 里 竜 瑛 